\title{
Amending Soil with Mulched European Buckthorn (Rhamnus cathartica) Does Not Reduce Reinvasion
}

\author{
Basil V. Iannone III, Lauren G. Umek, Liam Heneghan and David H. Wise
}

\begin{abstract}
We conducted a three-year field experiment to determine if amending soils with mulched European buckthorn (Rhamnus cathartica) can limit reinvasion, and whether two methods of incorporation-tilling or surface application-produce similar results. Mulch (a high carbon:nitrogen [C:N] material) may reduce reinvasion by stimulating soil microbial immobilization of $\mathrm{N}$. Converting the woody waste generated during buckthorn removal into mulch would also eliminate both the need to remove this waste from restoration sites and the expense of acquiring amendments from elsewhere. We found that adding buckthorn mulch to soils, whether tilled or not, did not decrease either buckthorn reinvasion or soil $\mathrm{N}$ availability. The mechanical disturbance of tilling, however, caused a large, prolonged reduction in reinvasion by killing a previously unrecognized but major contributor to reinvasion-small buckthorn individuals (most $<5 \mathrm{~cm}$ tall) that were undetected during initial removal. Recruitment of new individuals occurred during the experiment, but recruitment rate decreased rapidly over time, suggesting that buckthorn seeds are short-lived. Three major recommendations emerge: (1) buckthorn mulch should not be used to limit reinvasion; (2) tilling can greatly reduce reinvasion by killing buckthorn individuals that are undetected during initial removal; and (3) because buckthorn seeds appear to be short-lived, reinvasion can be reduced by repeated, annual follow-up control of undetected and newly recruited individuals.
\end{abstract}

Keywords: Age structure, carbon addition, root:shoot ratio, seed banks, soil disturbance

Tnvasions by exotic shrubs into tem- perate regions of North America are an increasing concern for conservation (Woods 1993, Catling 1997, Hutchinson and Vankat 1997, Ehrenfeld et al. 2001, Mascaro and Schnitzer 2007). While exotic shrubs invade at much slower rates than herbaceous plant invaders (Martin et al. 2009), many exotic shrub species possess two common traits of aggressive plants: vegetative reproduction (via stump resprouting) and prolific seed production (Ingold and Craycraft 1983, Luken and Mattimiro 1991, Archibold et al. 1997, Silander and Klepeis 1999). These traits likely contribute to exotic shrub invasion (Rejmánek and Richardson 1996,

Ecological Restoration Vol. 31, No. 3, 2013 ISSN 1522-4740 E-ISSN 1543-4079 @2013 by the Board of Regents of the University of Wisconsin System.
Rejmánek 2000) and reinvasion (Runkle et al. 2005, Heneghan et al. 2009). Reinvasion via stump resprouting can be greatly reduced by applying herbicide to recently cut stumps (Archibold et al. 1997, Hartman and McCarthy 2004). Reinvasion from remnant seed banks, however, can be more challenging to control (Drayton and Primack 1999, Adams and Galatowitsch 2006).

Invasions by aggressive plants, including exotic shrubs, are often associated with increases in available soil nitrogen (N) (Dukes and Mooney 1999, Ehrenfeld et al. 2001, Cassidy et al. 2004, Iannone 2013). If exotic shrubs preferentially establish in soils with high $\mathrm{N}$ availability (e.g. Iannone 2013), then decreasing this resource after exotic-shrub removal may limit reinvasion (Wedin and Tilman 1990). High carbon:nitrogen $(\mathrm{C}: \mathrm{N})$ ratio soil amendments (e.g. mulch, sawdust, and sucrose) can decrease soil $\mathrm{N}$ availability by stimulating soil microbial immobilization of $\mathrm{N}$ and in doing so, limit reinvasion by aggressive herbaceous plants (Alpert 2010, Perry et al. 2010). Whether or not such amendments limit reinvasion by slowergrowing exotic shrubs is unknown (Alpert 2010). A practical option might be to utilize the large amount of woody waste produced during exotic shrub removal as a source of high C:N mulch. This would reduce the need to remove the waste from restoration sites, as well as reduce the expense of acquiring another high $\mathrm{C}: \mathrm{N}$ ratio material from elsewhere.

While amending soils with mulch may limit reinvasion via soil $\mathrm{N}$ immobilization, we also hypothesized that tilling mulch into the soil may limit reinvasion by burying the remnant 
seed banks of exotic shrubs, thus limiting seedling emergence. Tilling, however, may also disturb soils or harm native seed banks or plants that persisted during invasion. In such situations, laying mulch on the soil surface, rather than tilling it into the soil, may still reduce reinvasion by decreasing soil N (Zink and Allen 1998). Determining how mulching reduces reinvasion (soil $\mathrm{N}$ immobilization vs. seed bank burial), and whether or not mulch needs to be tilled into the soil to do so, will assist in developing effective post-shrub removal restoration strategies.

We investigated whether amending soils with mulched European buckthorn (Rhamnus cathartica; hereafter buckthorn) can limit buckthorn reinvasion. Buckthorn, which invades both shaded and well-lit environments throughout much of North America (Kurylo et al. 2007), forms dense thickets, becoming a dominant component of the plant communities where it establishes (Catling 1997, Mascaro and Schnitzer 2007). After being removed, buckthorn reinvades via stump resprouting and potentially via its dense seed bank (Archibold et al. 1997). Soil mulch amendments may decrease buckthorn reinvasion as buckthorn preferentially establishes in high-ammonium $\left(\mathrm{NH}_{4}{ }^{+}-\mathrm{N}\right)$ soils (Iannone 2013). The objectives of this study were to determine: 1) if amending soils with buckthorn mulch reduces buckthorn reinvasion; 2) if buckthorn mulch needs to be tilled into the soil to cause this reduction; 3) if amending soils with buckthorn mulch decreases soil $\mathrm{N}$ availability; and 4) if tilling buries the remnant buckthorn seed bank. Objectives 3 and 4 will determine how mulching with buckthorn reduces reinvasion. This investigation may also help understand how soil $\mathrm{N}$ availability affects buckthorn establishment.

\section{Methods}

\section{Study Site}

The study site was located approximately $46 \mathrm{~km} \mathrm{NNW}$ of downtown Chicago on a 3-ha parcel of land managed by the Mettawa Openlands Association in Mettawa, IL, USA ( $\left.42^{\circ} 14^{\prime} 29^{\prime \prime} \mathrm{N}, 87^{\circ} 54^{\prime} 23^{\prime \prime} \mathrm{W}\right)$. The property is a former horse pasture that became invaded by buckthorn after horses were removed ca. 1990. In an effort to restore native prairie, the dense buckthorn thicket was cleared in 2007. During clearing, an approximately 0.3 -ha portion of the land was divided into forty-five $52-\mathrm{m}^{2}$ hexagonal plots that were used to investigate post-buckthorn removal restoration strategies. The study reported here was conducted in five of these plots (hereafter "blocks") where buckthorn was left standing. The soil in these blocks is a Nappanee silt loam (Aeric Epiaqualfs) (U.S. Department of Agriculture [USDA] 2012).

\section{Study Design and Establishment}

In the winter of 2008/2009, we divided each block into four $13-\mathrm{m}^{2}$ plots, and then removed and weighed the aboveground buckthorn from all plots. Analysis using linear mixedeffects (LME) models revealed that initial biomass did not differ significantly among plots $(p \geq 0.21$; range $=$ 43 to $357 \mathrm{~kg} /$ plot). To determine treatment effects on buckthorn resprouting, we did not apply herbicide to buckthorn stumps as is typically done. All plots within each block were randomly assigned one of two levels of mulching ("mulch" or "no mulch") and tilling ("till" or "no till"), creating a $2 \times 2$ randomized-block design with 5 replications ( $\mathrm{N}=20$; 4 plots/block). We applied treatments on 25 and 27 March 2009. We mulched the buckthorn harvested from our plots into approximately $0.5 \mathrm{~m}$ wide and $1-4 \mathrm{~m}$ long strips using a Vermeer BC625A brush chipper (Vermeer Corporation, Pella, IA, USA), and applied this mulch to the mulch treatment at a rate of $60 \mathrm{~kg} / \mathrm{plot}$. This rate lies within the range of rates used in prior investigations of soil C amendments (Morghan and Seastedt 1999, Averett et al. 2004) and was chosen after consulting a local practitioner (Doug DeWitt, Tallgrass Restoration, pers. comm.). The chemical composition of the mulch was (mean $\pm \mathrm{SD}$ ): total $\mathrm{C}=46.2 \pm 1.0 \%$; total $\mathrm{N}=0.7 \pm 0.1 \%$; $\mathrm{C}: \mathrm{N}$ ratio $=$ $72.2 \pm 9.6 ; \mathrm{NH}_{4}{ }^{+}-\mathrm{N}=34.0 \pm 11.0$ $\mu \mathrm{g} / \mathrm{g}$-dry mulch; and $\mathrm{NO}_{3}{ }^{-} \mathrm{N}=3.8$ $\pm 2.4 \mu \mathrm{g} / \mathrm{g}$-dry mulch. We tilled plots in the tilling treatment using both a Honda Mantis cultivator and a Honda F220 tiller (Honda Motor Co., Inc; Alpharetta, GA, USA), both of which tilled to an approximate depth of 20 $\mathrm{cm}$. We laid mulch evenly across the surface of plots receiving mulch, but no tilling. The experiment ran for three growing seasons (2009-2011).

The chemical composition of the buckthorn mulch was (mean \pm SD): total $\mathrm{C}=46.2 \pm 1.0 \%$; total $\mathrm{N}=0.7 \pm 0.1 \% ; \mathrm{C}: \mathrm{N}$ ratio $=72.2$ $\pm 9.6 ; \mathrm{NH}_{4}{ }^{+}-\mathrm{N}=34.0 \pm 11.0 \mu \mathrm{g} / \mathrm{g}-$ dry mulch; and $\mathrm{NO}_{3}{ }^{-}-\mathrm{N}=3.8 \pm 2.4$ $\mu \mathrm{g} / \mathrm{g}$-dry mulch. We determined total $\mathrm{C}$ and $\mathrm{N}$ content on 443 -mg dried, ground subsamples of buckthorn mulch using a CE Elantech Flash 2000 NC Soil Analyzer (CE Elantech Inc., Lakewood, NJ, USA) (Sollins et al. 1999). We extracted $\mathrm{NH}_{4}{ }^{+}-\mathrm{N}$ and $\mathrm{NO}_{3}{ }^{-}-\mathrm{N}$ from four 0.5 -g sub-samples of moist, ground buckthorn mulch using $80 \mathrm{~mL} 2 \mathrm{M} \mathrm{KCl}$ and estimated $\mathrm{NH}_{4}{ }^{+}-\mathrm{N}$ and $\mathrm{NO}_{3}{ }^{-}-\mathrm{N}$ concentrations in these extracts colormetrically using an EpochTM Microplate spectrophotometer (BioTek ${ }^{\oplus}$ Instruments, Inc., Highland Park, VT, USA) following methods described by Rhine et al. (1998) and Doane and Horwath (2003), respectively.

\section{Quantifying Buckthorn Reinvasion}

Buckthorn density -Each time we sampled buckthorn density, we did so in three randomly placed $0.25 \mathrm{~m}^{2}$ subplots. Each year, starting at bud break (when buckthorn leafed out; 


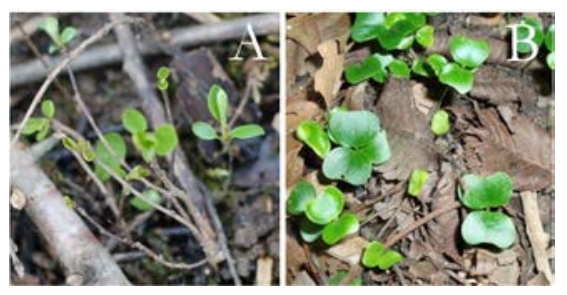

Figure 1. Buckthorn (Rhamnus cathartica) (A) yearlings and (B) seedlings with distinct cotyledons. Photograph B was taken by and used with permission by Carl Strang.

first week of April in 2009 and 2010; first week of May in 2011), we sampled buckthorn seedlings and yearlings every four weeks for six consecutive sampling periods. We define seedlings and yearlings as buckthorn individuals with and without cotyledons, respectively (Figure 1), and that therefore established during, or prior to, the growing season in which they were sampled. We sampled resprouts every 4 weeks for five consecutive sampling periods starting the first week of May in 2009 and 2010. We then harvested all resprouts (explained below). As buckthorn sprouts from stumps and not roots (Archibold et al. 1997), we could differentiate resprouts from yearlings and seedlings.

Buckthorn growth-We measured resprout biomass per plot and per stump, individual yearling biomass, and root:shoot ratios of yearlings. To limit effects of intraspecific competition on buckthorn yearling and seedling establishment and growth, we harvested all buckthorn resprouts from all plots between 10 and 14 September 2010. At this time we counted the buckthorn stumps in each plot. We dried resprouts under constant lighting for 6 weeks on greenhouse benches and weighed them. To prevent future resprouting, we applied a 1:1 mixture of water and glyphosate (N-(phosphonomethyl)glycine [Roundup; Monsanto Company, Saint Louis, MO, USA]) to stumps. At the end of the experiment (23 September 2011), we harvested all yearlings (roots and shoots) from three randomly placed $0.25 \mathrm{~m}^{2}$ subplots in each plot. We rinsed soil from roots, separated roots from shoots, and dried each at $70^{\circ} \mathrm{C}$ for 7 days before weighing.

Timing of reinvasion - We estimated the timing of reinvasion (buckthorn age structure) and the ratio of yearlings that established prior to, and after, treatment application by counting growth rings on either all yearlings harvested from each plot or a random sub-sample of 120 yearlings when their numbers were very high (range $=$ 8 to 238 individuals). Using a LEICA MZ12.5 dissecting microscope (Leica Microsystems Inc., Buffalo Grove, IL, USA), we counted growth rings on a $2 \mathrm{~mm}$ thick slice removed from the base of each yearling stem. To facilitate slicing and growth-ring detection, we soaked stems in tap water for $\sim 8$ hours.

\section{Quantifying the Proposed Mechanisms of Reduced Reinvasion}

Change in seed bank density-We estimated the change in seed bank density at $0 \mathrm{~cm}$ to $5 \mathrm{~cm}$ and $5 \mathrm{~cm}$ to $10 \mathrm{~cm}$ soil depths. To do so, we collected three $6 \mathrm{~cm} \times 10 \mathrm{~cm}$ soil cores from three random points in all plots prior to and after treatment application (24 March 2009 and 4 April 2009, respectively), divided these cores in half, shook soils vigorously for 2 minutes in a mixture of sodium bicarbonate (baking soda), sodium hexametaphosphate (Calgon (C), and magnesium sulfate (Epsom salt), and decanted all buckthorn seeds that rose to the surface (Malone 1967).

$N$ availability-We measured $\mathrm{NH}_{4}{ }^{+}-\mathrm{N}$ and $\mathrm{NO}_{3}{ }^{-} \mathrm{N}$ in a $6 \mathrm{~cm} \times$ $10 \mathrm{~cm}$ soil core collected from the center of each plot prior to treatment application, and then every 8 weeks starting at bud break (2 weeks after treatment application) for four consecutive sampling periods during 2009 and 2010. In 2011, we collected soils at bud break, 4 weeks later, and every 8 weeks for two more sampling periods. We stored soils at $-20^{\circ} \mathrm{C}$ until processed. We extracted $\mathrm{NH}_{4}{ }^{+}-\mathrm{N}$ and $\mathrm{NO}_{3}{ }^{-}-\mathrm{N}$ from moist 4-g sub-samples using $20 \mathrm{~mL}$ of $2 \mathrm{M} \mathrm{KCL}$ and then measured $\mathrm{NH}_{4}{ }^{+}-\mathrm{N}$ and $\mathrm{NO}_{3}{ }^{-} \mathrm{N}$ concentrations in these extracts using a Hach DR5000TM UV-Vis spectrophotometer (Hach Company, Loveland, CO, USA) (Robertson et al. 1999). We corrected readings for relative water content (RWC) (Jarrell et al. 1999) and reported values on a dry-weight basis (Robertson et al. 1999). Analysis using LME models revealed that neither soil $\mathrm{NH}_{4}{ }_{4}-\mathrm{N}$ nor $\mathrm{NO}_{3}{ }^{-}-\mathrm{N}$ differed significantly among plots prior to treatment application ( $p \geq 0.14$; range in $\mathrm{NH}_{4}{ }^{+}-\mathrm{N}=2.7$ to $10.1 \mathrm{mg} / \mathrm{kg}$; range in $\mathrm{NO}_{3}{ }^{-}-\mathrm{N}=4.9$ to $13.2 \mathrm{mg} / \mathrm{kg}$ ).

\section{Statistical Analyses}

We used univariate permutational analysis of variance (PERMANOVA) with Euclidean distances to analyze seedling density as this data was nonnormal (Anderson 2001). We analyzed changes in seed bank density and buckthorn age structure using multivariate PERMANOVA with Euclidean distances (Anderson 2001), with changes in seed bank density for each soil depth and the proportion of individuals that established in a given year as separate vectors. We estimated $p$-values using 10,000 random permutations on the residuals of reduced models (Anderson 2001). We analyzed all other response variables using LME models (Zuur et al. 2009).

Statistical models used to analyze response variables that were measured only once contained mulch, till, and their interaction as fixed effects, and block as a random effect. Statistical models used to analyze response variables that were measured multiple times contained the additional terms "year" and "sampling period" and all possible interactions as fixed effects, as well as plot nested within block as a random effect. We added stump count as a covariate for the analysis of resprout biomass per plot. To account for possible effects of intraspecific competition, we added final yearling density (ln transformed) and 
Table 1. Analysis of buckthorn density over time, including seedlings, yearlings, and resprouts. Numbers in parentheses are numerator degrees of freedom for the analysis of resprout density. $p$-values in bold type were statistically significant at the 0.05 level.

\begin{tabular}{|c|c|c|c|c|c|c|c|}
\hline \multirow[b]{2}{*}{ Model Term } & \multirow[b]{2}{*}{ df num } & \multicolumn{2}{|c|}{ Seedlings } & \multicolumn{2}{|c|}{ Yearlings* } & \multicolumn{2}{|c|}{ Resprouts** } \\
\hline & & df denom & $p$ & df denom & $p$ & df denom & $p$ \\
\hline RWC & 1 & 283 & 0.001 & 271 & 0.42 & 143 & 0.88 \\
\hline Stump Count & 1 & - & - & - & - & 143 & 0.004 \\
\hline Initial Biomass & 1 & - & - & - & - & 143 & 0.40 \\
\hline Mulch & 1 & 11 & 0.78 & 12 & 0.73 & 10 & 0.07 \\
\hline Till & 1 & 11 & 0.86 & 12 & 0.004 & 10 & 0.13 \\
\hline Sampling Period (SP) & $5(4)$ & 283 & 0.001 & 271 & 0.003 & 143 & 0.006 \\
\hline Year (Yr) & $2(1)$ & 283 & 0.001 & 271 & $<0.0001$ & 143 & 0.15 \\
\hline Mulch $\times$ Till & 1 & 11 & 0.30 & 12 & 0.62 & 10 & 0.14 \\
\hline Mulch $\times$ SP & $5(4)$ & 283 & 0.83 & 271 & $<0.0001$ & 143 & 0.88 \\
\hline Mulch $\times$ Yr & $2(1)$ & 283 & 0.57 & 271 & $<0.0001$ & 143 & 0.007 \\
\hline Till $\times$ SP & $5(4)$ & 283 & 0.87 & 271 & 0.39 & 143 & 0.07 \\
\hline Till $\times$ Yr & $2(1)$ & 283 & 0.004 & 271 & 0.003 & 143 & 0.07 \\
\hline $\mathrm{SP} \times \mathrm{Yr}$ & $10(4)$ & 283 & 0.001 & 271 & 0.0006 & 143 & 0.002 \\
\hline Mulch $\times$ Till $\times$ SP & $5(4)$ & 283 & 1.00 & 271 & 0.02 & 143 & 0.45 \\
\hline Mulch $\times$ Till $\times$ Yr & $2(1)$ & 283 & 0.40 & 271 & 0.05 & 143 & 0.10 \\
\hline Mulch $\times S P \times Y r$ & $10(4)$ & 283 & 0.89 & 271 & 0.0001 & 143 & 0.07 \\
\hline Till $\times$ SP $\times$ Year & $10(4)$ & 283 & 0.64 & 271 & 0.68 & 143 & 0.65 \\
\hline Mulch $\times$ Till $\times$ SP $\times$ Yr & $10(4)$ & 283 & 0.92 & 271 & 0.23 & 143 & 0.27 \\
\hline
\end{tabular}

* Values were sqrt-transformed.

** Values were sqrt-transformed, and the model allowed for heterogeneous variance in residuals across levels of tilling.

resprout biomass per plot as covariates to the analyses of yearling biomass and root:shoot ratios, and also added final yearling density to the analysis of age structure. We used Spearman rank correlations to determine if RWC and initial buckthorn biomass were related to all response variables, and if initial soil $\mathrm{NH}_{4}{ }^{+}-\mathrm{N}$ and $\mathrm{NO}_{3}{ }^{-} \mathrm{N}$ levels were related to soil $\mathrm{NH}_{4}{ }^{+}-\mathrm{N}$ and $\mathrm{NO}_{3}{ }^{-}-\mathrm{N}$ levels during the study. If so, we added these terms as covariates. We transformed data and/or allowed for heterogeneous variance across levels, or ranges, of model terms if doing so improved model residuals (see appropriate tables for details) (Zuur et al. 2009). We used PERMANOVA+ v 1.0.2 (Anderson et al. 2008) to conduct PERMANOVAs, and R v 2.14.1 (R Development Core Team 2011) to conduct LME models and Spearman rank correlations. We report all results as mean $\pm \mathrm{SE}$.

\section{Results}

\section{Buckthorn Reinvasion}

The mechanical disturbance of tilling reduced reinvasion, while mulch, regardless of whether it was tilled into the soil, had no effect on reinvasion.

Buckthorn density-Each year we did not detect seedlings until 4 to 8 weeks after yearling bud break (between early May and early June). Over the three years, overall seedling density decreased by $91 \%$ (Table 1 ; Figure 2). Mulching did not significantly affect seedling density (Table 1). Although mulching reduced yearling densities by $71 \%$ (from 100 \pm 39 to $29 \pm 13$ yearlings $/ \mathrm{m}^{2}$ ) and $61 \%$ (from $133 \pm 60$ to $52 \pm 20$ yearlings $\left./ \mathrm{m}^{2}\right)$ in the first two sampling periods of 2009 (April and May), respectively, this reduction did not persist beyond this period (Table 1). Mulching reduced resprout density by $36 \%$ in 2009 (from $32.4 \pm 4.1$ to $20.8 \pm 3.3$ resprouts $/ \mathrm{m}^{2}$ ), but not in $2010\left(28.0 \pm 2.3\right.$ resprouts $/ \mathrm{m}^{2}$; Table $1)$. Tilling reduced seedling density by $39 \%$ in 2009 , but not in 2010 and 2011 (Table 1; Figure 2). Tilling reduced yearling density by $79-86 \%$ over the three growing seasons, while tilling mulch into the soil reduced yearling density by an additional $9 \%$ and $12 \%$ beyond tilling alone in 2009 and 2011, respectively (Table 1, Figure 3). Tilling did not significantly reduce resprout density (Table 1 ).

Buckthorn growth-Buckthorn yearling biomass was $82 \%$ lower when mulch was tilled into the soil than when it was laid across the soil surface (Table 2; Figure 4). Pairwise comparisons between plots that were either tilled, mulched, or both, and plots that were neither tilled nor mulched (i.e., comparisons most relevant to management), however, revealed that neither tilling nor mulching caused this reduction (Figure 4). Nonetheless, yearling biomass was greatest in plots where mulch was laid across the soil surface (Figure 4). Neither tilling nor mulching significantly affected yearling root:shoot ratios $(1.07 \pm 0.05$; Table 2). 


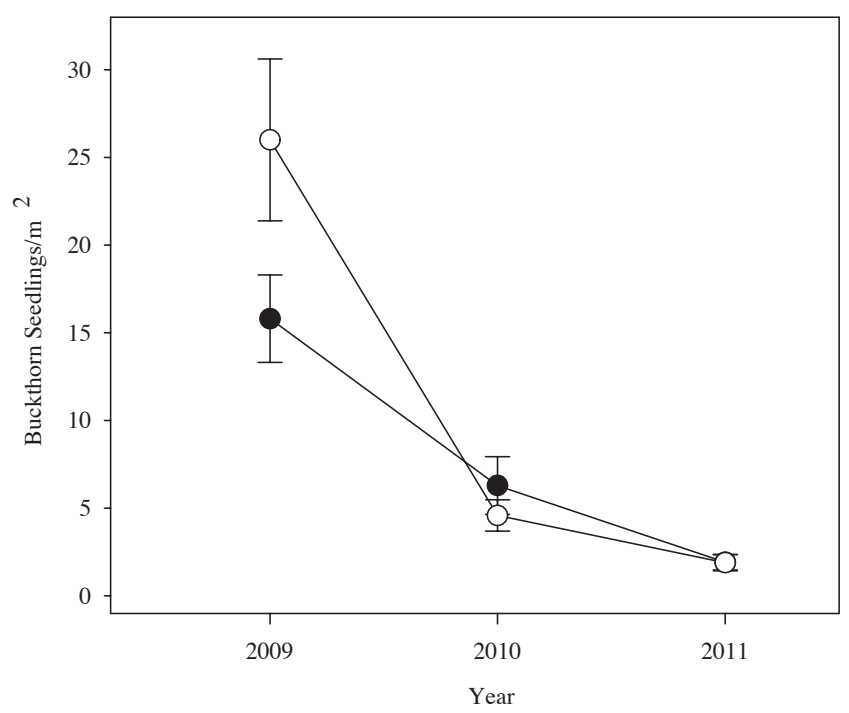

Figure 2. The effects of tilling on buckthorn seedling density over time ( $p=0.004)$. Tilled plots (black circles) had lower seedling densities than non-tilled plots (white circles) in 2009, but not in subsequent years. Overall seedling density decreased greatly over time. Mean $\pm \mathrm{SE}$.

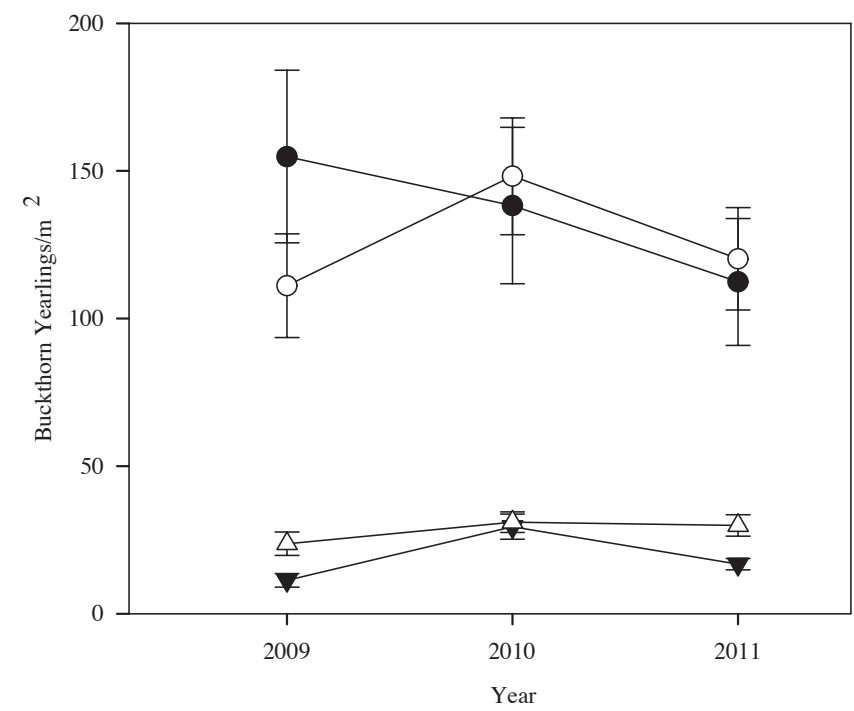

Figure 3. The effects of mulch $x$ till interaction on buckthorn yearling density over time $(p=0.05)$. Black circles = non-mulched, non-tilled plots. White circles $=$ mulch-only plots. White triangles $=$ till-only plots. Black triangles $=$ mulched, tilled plots. Tilling greatly reduced yearling densities throughout the experiment, while tilling mulch into the soil caused slightly more reduction than tilling alone in 2009 and 2011. Mean \pm SE.
Tilling, but not mulching, may have reduced resprout biomass per plot (Table 2). One tilled plot had resprout biomass $(9.4 \mathrm{~kg} / \mathrm{plot})$ that was 34\% greater than all other plots, and $98 \%$ greater than all other tilled plots. When this plot was removed from the analysis, tilling reduced total resprout biomass by $49 \%$ (from $4.2 \pm$ 0.5 to $2.1 \pm 0.5 \mathrm{~kg} / \mathrm{plot}$ ). There was no significant effect of tilling on total resprout biomass when this plot was left in the analysis $(3.5 \pm 0.5 \mathrm{~kg} / \mathrm{plot}$;
Table 2). Neither tilling nor mulching significantly affected resprout biomass per stump $(0.06 \pm 0.01 \mathrm{~kg} /$ stump; Table 2). Despite resprouts being much taller than yearlings $(1 \mathrm{~m}$ vs. $<15 \mathrm{~cm}$, respectively), and being abundant in all plots, resprout biomass did not affect yearling growth (Table 2).

Timing of reinvasion (buckthorn age structure)—Although seedling density

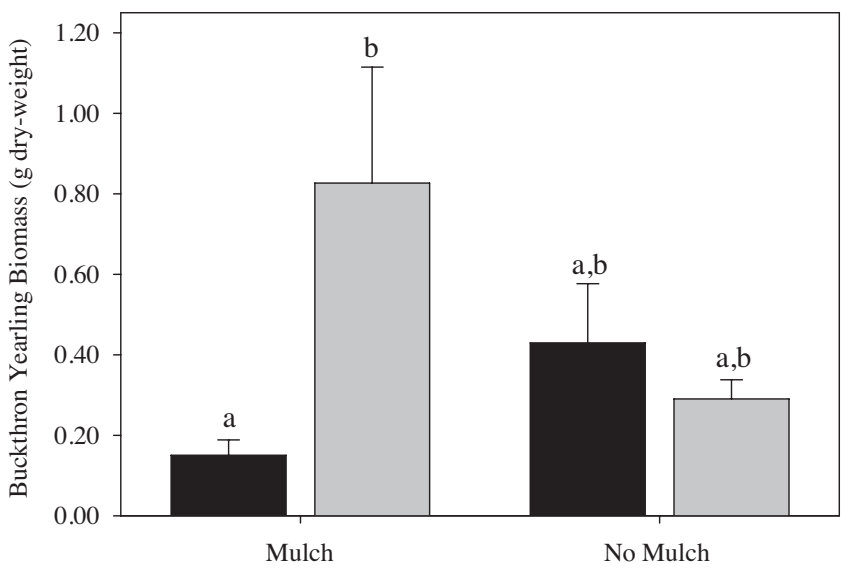

Figure 4. The effects of the mulch $x$ till interaction on individual yearling biomass (root plus shoot growth; $p=0.003$ ). Permutational pairwise comparisons revealed that yearlings growing in mulched plots where mulch was tilled into the soil (black bars) were smaller than yearlings growing in mulched plots where mulch was laid on the soil surface (grey bars) $(p=0.003)$. Bars with different letters are significantly different from one another. These treatment combinations, however, did not differ significantly from all others ( $p s \geq 0.13$ ). Mean \pm SE.

decreased greatly and yearling density changed little over time (Figures 2 and $3)$, buckthorn reinvaded throughout the experiment (Figure 5). Buckthorn reinvaded later in plots that were both mulched and tilled than in plots that were only tilled (Table 3; Figure 5). The age structure of these treatment combinations, however, did not differ significantly from that of other treatment combinations (Figure 5). Neither tilling nor mulching affected the ratio of yearlings that established prior to, and after, treatment application (proportion established before $=0.34$ \pm 0.05 ; proportion established after $=$ $0.66 \pm 0.05)$ (Table 3).

\section{Proposed Mechanisms for Reducing Reinvasion}

Change in buckthorn seed bank density —Seed bank densities in the $0 \mathrm{~cm}$ to $5 \mathrm{~cm}$ and $5 \mathrm{~cm}$ to $10 \mathrm{~cm}$ soil depths did not change in response to either tilling or mulching (Table 3). However, seed bank densities were high and heterogeneous across all plots $(710 \pm$ 100 and $110 \pm 30$ seeds $/ \mathrm{m}^{2}$ in $0 \mathrm{~cm}$ to $5 \mathrm{~cm}$ and $5 \mathrm{~cm}$ to $10 \mathrm{~cm}$ soil depths, respectively). 
Table 2. Analysis of buckthorn growth: individual yearling biomass, root:shoot ratio, resprout biomass/plot, and resprout biomass/stump. Final Yr Den = final density of yearlings at the end of the experiment and Final Resprout $=$ Resprout biomass harvested in 2010. $p$-values in bold type are statistically significant at the 0.05 level. $p$-values in parentheses for resprout biomass/plot are for analysis without the one very high value described in the results.

\begin{tabular}{|c|c|c|c|c|c|c|c|c|c|}
\hline \multirow[b]{2}{*}{ Model Term } & \multirow[b]{2}{*}{ df num } & \multicolumn{2}{|c|}{$\begin{array}{c}\text { Individual Yearling } \\
\text { Biomass* }\end{array}$} & \multicolumn{2}{|c|}{ Root:Shoot Ratio** } & \multicolumn{2}{|c|}{ Resprout Biomass/Plot } & \multicolumn{2}{|c|}{$\begin{array}{l}\text { Resprout Biomass } \\
\text { Stump }\end{array}$} \\
\hline & & df denom & $p$ & df denom & $p$ & df denom & $p$ & df denom & $p$ \\
\hline RWC & 1 & 9 & 0.38 & - & - & - & - & - & - \\
\hline Stump Count & 1 & - & - & - & - & 11 & $0.42(0.09)$ & - & - \\
\hline In(Final Yr Den) & 1 & 9 & 0.05 & 10 & 0.03 & - & - & - & - \\
\hline Final Resprout & 1 & 9 & 0.75 & 10 & 0.21 & - & - & - & - \\
\hline Mulch & 1 & 9 & 0.37 & 10 & 0.12 & 11 & $0.96(0.23)$ & 12 & 0.52 \\
\hline Till & 1 & 9 & 0.005 & 10 & 0.61 & 11 & $0.20(\mathbf{0 . 0 1})$ & 12 & 0.29 \\
\hline Mulch $\times$ Till & 1 & 9 & 0.006 & 10 & 0.09 & 11 & $0.99(0.19)$ & 12 & 0.60 \\
\hline
\end{tabular}

* Values were In-transformed.

** Model allowed for heterogeneous variance in residuals across levels of till.

*** Values were In-transformed, and model allowed for heterogeneous variance in residuals across both the range in In(final yearling density) and levels of till.

Soil $N$ availability_-Tilling, but not mulching, decreased soil $\mathrm{N}$ availability. Throughout the experiment, tilling slightly decreased (15\%) both soil $\mathrm{NH}_{4}{ }^{+}-\mathrm{N}$ (from $12.1 \pm 0.6$ to 10.2 $\pm 0.5 \mathrm{mg} / \mathrm{kg}$ ) and $\mathrm{NO}_{3}{ }^{-}-\mathrm{N}$ (from 3.5 \pm 0.3 to $2.9 \pm 0.3 \mathrm{mg} / \mathrm{kg}$ ) (Table 4 ). Mulch increased soil $\mathrm{NH}_{4}{ }^{+}-\mathrm{N}$ by $21 \%$ in 2010, but did not significantly affect soil $\mathrm{NH}_{4}{ }^{+}-\mathrm{N}$ in 2009 or 2011 (Table 4; Figure 6). Mulch did not significantly affect soil $\mathrm{NO}_{3}{ }^{-}-\mathrm{N}$ (Table 4; Figure 6).

\section{Discussion}

\section{Utility of Buckthorn Mulch}

Our study revealed that amending soils with buckthorn mulch by either laying it on or tilling it into the soil will not limit buckthorn reinvasion. The mechanical disturbance of tilling, despite burying buckthorn seeds, was what reduced reinvasion. Tilling mulch into the soil reduced yearling density only slightly beyond tilling alone, further confirming this finding. The brief, 8-week reduction in yearling density caused by mulching was likely due to mulch burying, rather than killing yearlings. Additionally, buckthorn yearlings grew best in mulch-only plots, suggesting that managers should avoid surface application of mulch-a practice common where buckthorn is removed with heavy machinery (Doug DeWitt, Tallgrass Restoration, pers. comm.). The temporary reduction in resprout density caused by mulching is irrelevant to management as resprouts were still abundant in mulched plots. Finally, buckthorn mulch increased, rather than decreased, soil $\mathrm{N}$ availability. These findings also emphasize that studies examining the effects on reinvasion of tilling a high $\mathrm{C}: \mathrm{N}$ ratio amendment into the soil need to isolate the effects of tilling the amendment into the soil from those of the actual amendment.

\section{Further Considerations for Soil Mulch Amendments}

The reasons why buckthorn mulch increased, rather than decreased, soil $\mathrm{N}$ availability are unclear. This increase prevented us from determining the relationship between soil $\mathrm{N}$ availability and buckthorn establishment. It is unlikely that buckthorn's $\mathrm{NH}_{4}{ }^{+}-\mathrm{N}$ concentration increased soil $\mathrm{NH}_{4}{ }^{+}-\mathrm{N}$, as amendments with similar $\mathrm{NH}_{4}{ }^{+}-\mathrm{N}$ concentrations do not have this effect (Iannone et al. 2009). The C:N ratio of buckthorn mulch $(-72)$, although low compared to that of other woody tissues [e.g. pine $=-227$; red oak $=$ -330 (Iannone et al. 2009)], is still above the ratio required to immobilize N [ -30-35 (Stevenson and Cole 1986)]. Nonetheless, applying more mulch may have decreased available

Table 3. Analysis of buckthorn age structure (i.e., timing of reinvasion), ratio of yearlings that established prior to and after treatment application (establishment ratio), and changes in seed bank density. $p$-values in bold type are statistically significant at the 0.05 level.

\begin{tabular}{|c|c|c|c|c|c|c|c|}
\hline \multirow[b]{2}{*}{ Model Term } & \multirow[b]{2}{*}{ df num } & \multicolumn{2}{|c|}{ Buckthorn Age Structure } & \multicolumn{2}{|c|}{ Establishment Ratio* } & \multicolumn{2}{|c|}{ Change in Seed Bank Density } \\
\hline & & df denom & $p$ & df denom & $p$ & df denom & $p$ \\
\hline RWC & 1 & - & - & 10 & 0.08 & - & - \\
\hline Initial Biomass & 1 & - & - & - & - & 11 & 0.94 \\
\hline In(Final Sap Den) & 1 & 11 & 0.06 & 10 & 0.05 & - & - \\
\hline Mulch & 1 & 11 & 0.19 & 10 & 0.77 & 11 & 0.49 \\
\hline Till & 1 & 11 & 0.40 & 10 & 0.78 & 11 & 0.53 \\
\hline Mulch $\times$ Till & 1 & 11 & 0.03 & 10 & 0.87 & 11 & 0.55 \\
\hline
\end{tabular}

*Model allowed for heterogeneous variance in residuals across levels of till. 


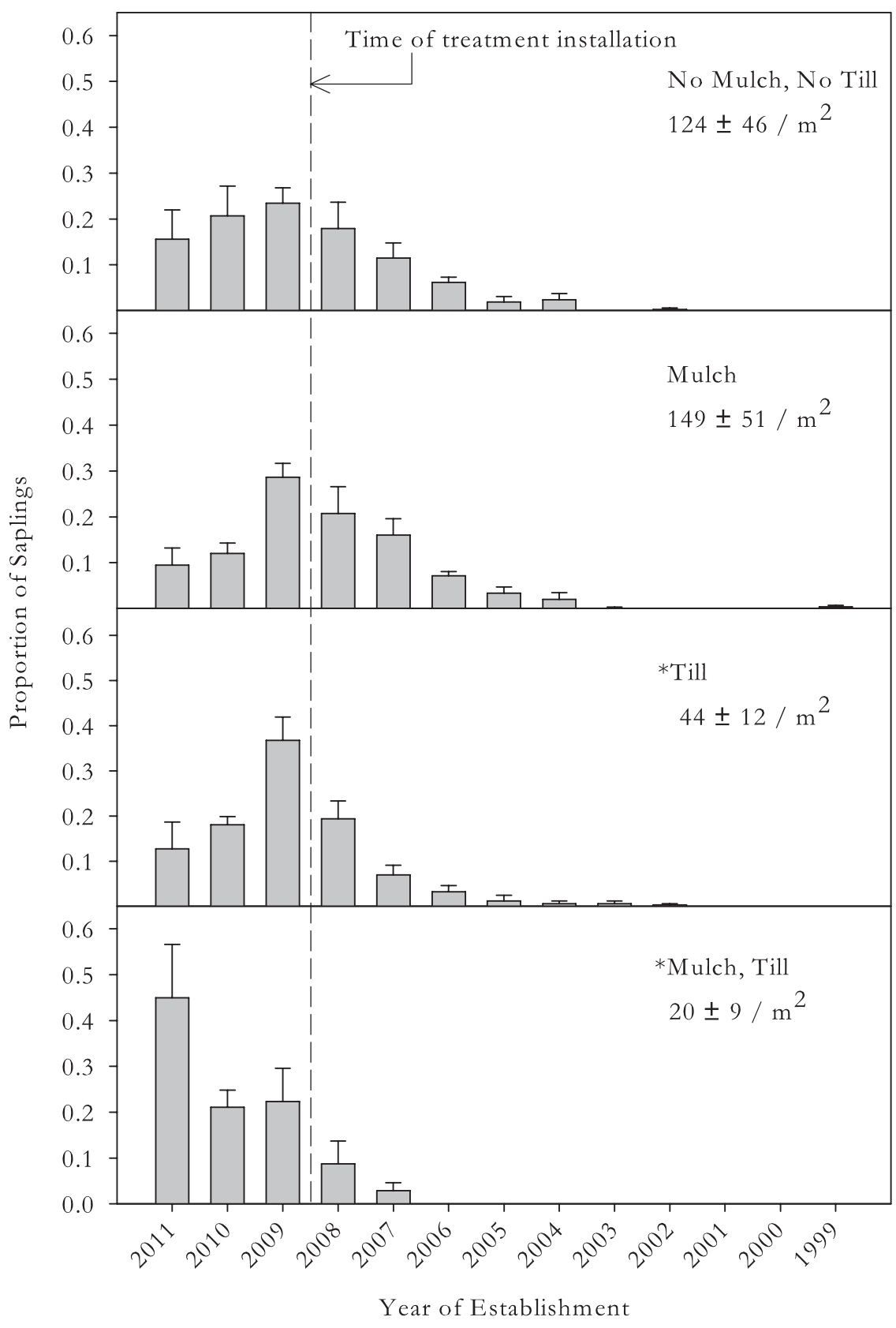

Figure 5. The effects of mulch $x$ till interaction on timing of reinvasion (buckthorn age structure) $(p=0.03)$. Values are the mean \pm SE yearling density at the end of the experiment. Bars show what proportion of those yearlings established in what year. NOTE: time goes backwards on the horizontal-axis to convey yearling age, i.e., yearlings establishing in 2011 were younger than those establishing in $\mathbf{2 0 1 0}$ or earlier. Permutational pairwise comparisons revealed that till and mulch-till treatments differed from one another ( $p=0.04$; denoted by asterisks). These treatment combinations, however, did not differ significantly from all others ( $p s \geq 0.23$ ).

$\mathrm{N}$ (Blumenthal et al. 2003). As we sampled soils 2 weeks after mulching and every 8 weeks thereafter, it is unlikely that buckthorn mulch caused a decrease in soil $\mathrm{N}$ that was too brief to detect. Mulch's low surface area:volume ratio, relative to other high C:N ratio materials (e.g., sawdust or sucrose), may limit microbial higher $\mathrm{C}: \mathrm{N}$ ratios and/or higher surface area:volume ratios than buckthorn mulch.

\section{Implications for Control}

We applied a tilling treatment to isolate the effects of tilling mulch into the soil from those of mulching per se, and not to evaluate its utility as a control strategy. Nonetheless, understanding how tilling caused prolonged reductions in reinvasion can help to devise better control strategies. Tilling greatly reduced yearling density 8 weeks before the emergence of buckthorn seedlings. After seedlings emerged, yearling density changed very little, suggesting that recruitment of new buckthorn during the experiment was low and that buckthorn individuals establishing prior to treatment application, i.e., that were undetected during initial removal, were the major source of reinvasion. If so, killing undetected buckthorn individuals during the growing season following removal should greatly reduce reinvasion.

Undetected individuals may play a large role in many exotic shrub reinvasions. Managers are encouraged to remove exotic shrubs in the winter to limit disturbances to soil, native plants, and native animals (Simoni et al. 2012). However, winter snow cover could easily hide small individuals, allowing them to trigger reinvasion (Moody and Mack 1988). For example, most undetected buckthorn yearlings in this experiment were under $5 \mathrm{~cm}$ during the first growing season. Additionally, exotic shrubs, when being cleared, are typically large $(\sim 4 \mathrm{~m}$ tall at our site). Given the effort required to remove large shrubs with loppers, hand saws, and chain saws, it is easy to understand why much smaller individuals go undetected.

Contrary to estimates of yearling density, estimates of age structure revealed that seedling establishment occurred after treatment application. Long-term reduction in buckthorn reinvasion will therefore require follow-up control of new recruits in 
Table 4. Analysis of soil $\mathrm{NH}_{4}{ }^{+}-\mathrm{N}$ and soil $\mathrm{NO}_{3}{ }^{-}-\mathrm{N}$ over time. $p$-values in bold type are statistically significant at the 0.05 level.

\begin{tabular}{|c|c|c|c|c|c|}
\hline \multirow[b]{2}{*}{ Model Term } & \multirow[b]{2}{*}{ df num } & \multicolumn{2}{|c|}{$\mathrm{NH}_{4}^{+}-\mathrm{N}^{*}$} & \multicolumn{2}{|c|}{$\mathrm{NO}_{3}{ }^{-}-\mathrm{N}^{* *}$} \\
\hline & & df denom & $p$ & df denom & $p$ \\
\hline RWC & 1 & 174 & 0.003 & 175 & 0.30 \\
\hline Initial $\mathrm{NH}_{4}^{+}-\mathrm{N}$ & 1 & 174 & 0.06 & - & - \\
\hline Mulch & 1 & 11 & 0.08 & 12 & 0.96 \\
\hline Till & 1 & 11 & 0.03 & 12 & 0.03 \\
\hline Sampling Period (SP) & 3 & 174 & $<0.0001$ & 175 & $<0.0001$ \\
\hline Year (Yr) & 2 & 174 & $<0.0001$ & 175 & $<0.0001$ \\
\hline Mulch $\times$ Till & 1 & 11 & 0.28 & 12 & 0.62 \\
\hline Mulch $\times$ SP & 3 & 174 & 0.14 & 175 & 0.50 \\
\hline Mulch $\times \mathrm{Yr}$ & 2 & 174 & 0.01 & 175 & 0.63 \\
\hline Till $\times$ SP & 3 & 174 & 0.88 & 175 & 0.46 \\
\hline Till $\times$ Yr & 2 & 174 & 0.33 & 175 & 0.88 \\
\hline$S P \times Y r$ & 6 & 174 & $<0.0001$ & 175 & $<0.0001$ \\
\hline Mulch $\times$ Till $\times$ SP & 3 & 174 & 0.62 & 175 & 0.34 \\
\hline Mulch $\times$ Till $\times$ Yr & 2 & 174 & 0.48 & 175 & 0.52 \\
\hline Mulch $\times \mathrm{SP} \times \mathrm{Yr}$ & 6 & 174 & 0.06 & 175 & 0.43 \\
\hline Till $\times$ SP $\times$ Year & 6 & 174 & 0.81 & 175 & 0.74 \\
\hline Mulch $\times$ Till $\times$ SP $\times$ Yr & 6 & 174 & 0.71 & 175 & 0.45 \\
\hline
\end{tabular}

*Model allowed for heterogeneous variances across levels of both sampling period and year.

${ }^{*}$ Values were sqrt-transformed, and model allowed for heterogeneous variances across levels of both sampling period and year.

addition to elimination of initially undetected individuals. Nonetheless, the small change in yearling density over time suggests that buckthorn mortality and recruitment were occurring at similar rates. The rapid decline in seedling density over time further suggests that the seed bank was largely depleted three years after initial control. This rapid depletion is plausible, as exotic shrubs can persist in low-light environments (Martin et al. 2009), thus limiting their need for longterm seed dormancy (Grime 1977). However, to test this hypothesis, seed bank densities need to be measured throughout future studies. Therefore, so long as initially undetected individuals are removed, the number of new recruits requiring follow-up control should remain low, and repeated annual follow-up control starting in the growing season following initial removal may result in longer-term reductions in reinvasion than typically noted (Runkle et al. 2005, Heneghan et al. 2009).

Herbicide may be more appropriate for repeated, annual follow-up control than the often-recommended prescribed fire (Packard and Mutel

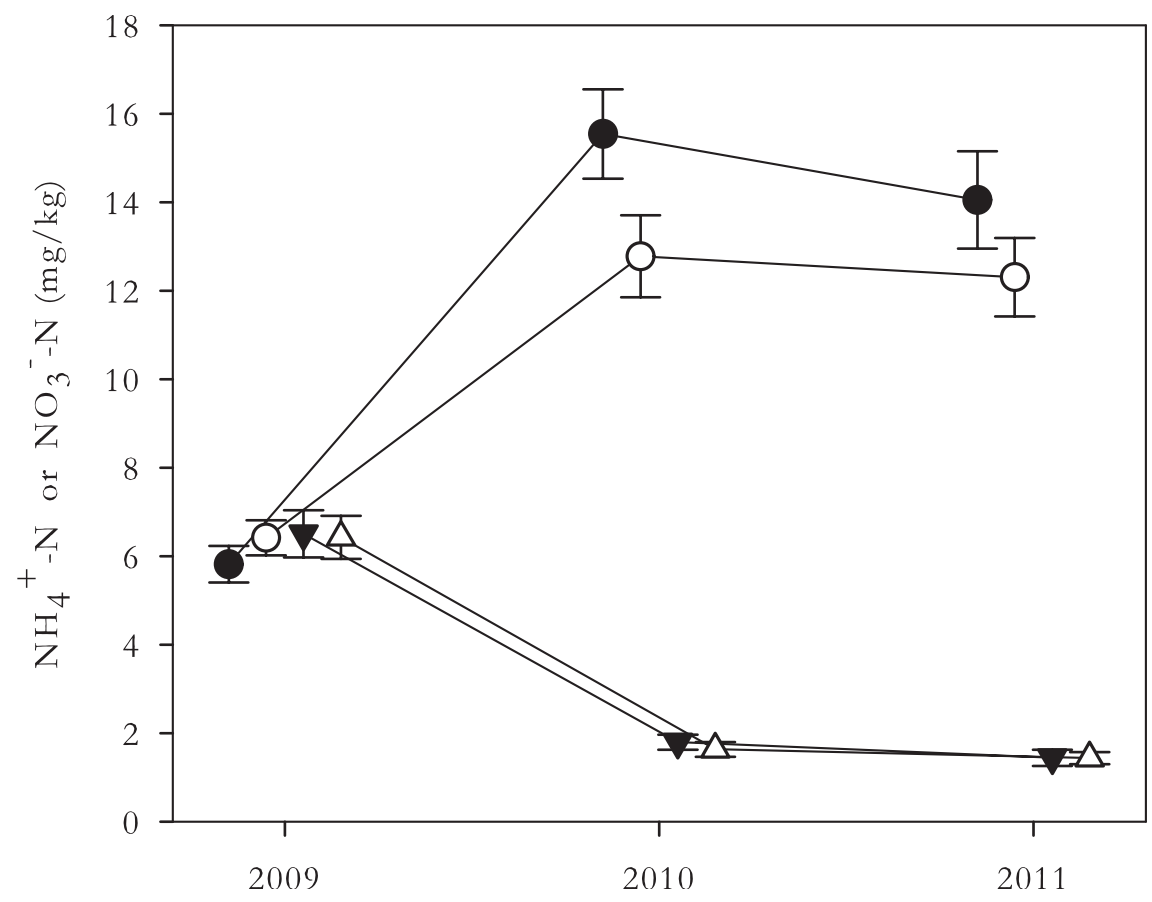

Figure 6. The effects of mulch on soil $\mathrm{NH}_{4}{ }^{+}-\mathrm{N}$ or $\mathrm{NO}_{3}{ }^{-} \mathrm{N}$ over time. Soil $\mathrm{NO}_{3}{ }^{-}-\mathrm{N}$ did not differ significantly between mulched (black triangles) and non-mulched (white triangles) plots. Soil $\mathrm{NH}_{4}^{+}-\mathrm{N}$ was $21 \%$ higher in mulched (black circles) than non-mulched (white circles) plots in 2010, but did not differ significantly between these treatments during any other growing season $(p=$ 0.01). Mean $\pm S E$.

1997), as herbicides can be applied annually without delay. In contrast, multi-year delays in burning can occur while waiting either for fuel load (i.e., plant litter) to build up (particularly in light-limited woodlands), or for suitable weather. Managers should also continue to apply herbicide to stumps in order to reduce resprouting (Archibold et al. 1997, Hartman 
and McCarthy 2004), since neither tilling nor mulching reduced resprouting enough to be an effective control strategy.

Finally, the prolonged reduction in reinvasion caused by tilling revealed that managers should consider using tilling as a control strategy. While tilling may not be feasible in woodlands and may disrupt extant native seed banks and native plants, it could easily be applied without concern in open and degraded sites with no or few native seeds or native plants, although alternative tilling methods than we used will be required for larger restoration projects.

\section{Acknowledgements}

Funding was provided by NSF Grants DGE-0549245 and DEB-BE-0909452; the Institute for Environmental Science and Policy, and the Graduate College, at UIC; a J.E. Weaver Competitive Grant from the Nebraska Chapter of the Nature Conservancy; a Garden Club of America Zone VI Fellowship in Urban Forestry; the Gaylord and Dorothy Donnelley Foundation; the Gutgsell Family Foundation; the DePaul College of Liberal Arts and Sciences; the Program in Plant Biology and Conservation at Northwestern University; the Chicago Botanic Garden; and the UIC Research Open Access Article Publishing (ROAAP) Fund. Thanks to: T. Murphy for installing and managing the earlier stages of this experiment; Mettawa Openlands Association; K. Ross, H. BassiriRad, Integrated Lakes Management, and Tallgrass Restoration for advice; M. Gonzalez-Meler for the use of his lab; and C. Baugher, E. Bayliss, J. Beard, S. Chadha, C. Carey, J. Chaffin, S. Charlino, A. Dickerson, K. Elhert, M. Farfan, C. Gill, A.M. Iannone, M. Kern, A. Kligman, E. Kosson, M. McCary, L. Miller, R. Mores, A. North, J. Peralta, D. Rijal, P. Rothrock, C. Saari, R. Sliwinski, K. Soler, K. Villarin, W. Warner, R. Weitholter, J. Wexler, E. White, and H. Zayyad for their field and lab assistance. Comments from three anonymous reviewers improved the quality of this paper.

\section{References}

Adams, C.R. and S.M. Galatowitsch. 2006. Increasing the effectiveness of reed canary grass (Phalaris arundinacea L.) control in wet meadow restorations. Restoration Ecology 14:441-451.

Alpert, P. 2010. Amending invasion with carbon: After fifteen years, a partial success. Rangelands 32:12-15.

Anderson, M.J. 2001. Permutation tests for univariate or multivariate analysis of variance and regression. Canadian Journal of Fisheries and Aquatic Sciences 58:626-639.

Anderson, M.J., R.N. Gorley and K.R. Clarke. 2008. PERMANOVA+ for PRIMER: Guide to Software and Statistical Methods. Plymouth: PRIMERE Ltd.

Archibold, O.W., D. Brooks and L. Delanoy. 1997. An investigation of the invasive shrub European buckthorn, Rhamnus cathartica L., near Saskatoon, Saskatchewan. Canadian FieldNaturalist 111:617-621.

Averett, J.M., R.A. Klips, L.E. Nave, S.D. Frey and P.S. Curtis. 2004. Effects of soil carbon amendment on nitrogen availability and plant growth in an experimental tallgrass prairie restoration. Restoration Ecology 12:568-574.

Blumenthal, D.M., N.R. Jordan and M.P. Russelle. 2003. Soil carbon addition controls weeds and facilitates prairie restoration. Ecological Applications 13:605-615.

Cassidy, T.M., J.H. Fownes and R.A. Harrington. 2004. Nitrogen limits an invasive perennial shrub in forest understory. Biological Invasions 6:113-121.

Catling, P.M. 1997. The problem of invading alien trees and shrubs: some observations in Ontario and a Canadian checklist. Canadian Field Naturalist 111:338-342.

Cornwell, W.K., J.H.C. Cornelissen, S.D. Allison, J. Bauhus, P. Eggleton, C.M. Preston, F. Scarff, J.T. Weedon, C. Wirth and A.E. Zanne. 2009. Plant traits and wood fates across the globe: Rotted, burned, or consumed? Global Change Biology 15:2431-2449.

Doane, T.A. and W.R. Horwath. 2003. Spectrophotometric determination of nitrate with a single reagent. Analytical Letters 36:2713-2722.

Drayton, B. and R.B. Primack. 1999. Experimental extinction of garlic mustard (Alliaria petiolata) populations: Implications for weed science and conservation biology. Biological Invasions 1:159-167.

Dukes, J.S. and H.A. Mooney. 1999. Does global change increase the success of biological invaders? Trends in Ecology \& Evolution 14:135-139.

Ehrenfeld, J.G., P. Kourtev and W.Z. Huang. 2001. Changes in soil functions following invasions of exotic understory plants in deciduous forests. Ecological Applications 11:1287-1300.

Grime, J.P. 1977. Evidence for existence of three primary strategies in plants and its relevance to ecological and evolutionary theory. American Naturalist 111:1169-1194.

Hartman, K.M. and B.C. McCarthy. 2004. Restoration of a forest understory after the removal of an invasive shrub, Amur honeysuckle (Lonicera maackii). Restoration Ecology 12:154-165.

Heneghan, L., L. Umek, B. Bernau, K. Grady, J. Iatropulos, D. Jabon and M. Workman. 2009. Ecological research can augment restoration practice in urban areas degraded by invasive species: Examples from Chicago Wilderness. Urban Ecosystems 12:63-77.

Hutchinson, T.F. and J.L. Vankat. 1997. Invasibility and effects of Amur honeysuckle in southwestern Ohio forests. Conservation Biology 11:1117-1124.

Iannone, B.V. III. 2013. Utilizing multiple approaches to investigate the ecology of Rhamnus cathartica L. invasion and management. PhD dissertation, University of Illinois at Chicago.

Iannone, B.V. III, C.J. Rosen and S.M. Galatowitsch. 2009. Soil nitrogen concentrations in a restored sedge meadow wetland as affected by the application of high C:N amendments. Ecological Restoration 27:193-199.

Ingold, J.L. and M.J. Craycraft. 1983. Avian frugivory on honeysuckle (Lonicera) in southwestern Ohio in fall. The Ohio Journal of Science 83:256-258.

Jarrell, W.M., D.E. Armstrong, D.F. Grigal, E.F. Kelly, H.C. Monger and D.A. Wedin. 1999. Soil water and temperature status. Pages 55-73 in G.P. Robertson, D.C. Coleman, C.S. Bledsoe, and P. Sollins (eds), Standard Soil Methods for Long-Term Ecological Research. New York: Oxford University Press.

Kurylo, J.S., K.S. Knight, J.R. Stewart and A.G. Endress. 2007. Rhamnus cathartica: native and naturalized distribution and habitat preferences. The Journal of the Torrey Botanical Society 134:420-430. 
Luken, J.O. and D.T. Mattimiro. 1991. Habitat-specific resilience of the invasive shrub Amur honeysuckle (Lonicera maackii) during repeated clipping. Ecological Applications 1:104-109.

Malone, C.R. 1967. A rapid method for enumeration of viable seeds in soil. Weeds 15:381-382.

Martin, P.H., C.D. Canham and P.L. Marks. 2009. Why forests appear resistant to exotic plant invasions: Intentional introductions, stand dynamics, and the role of shade tolerance. Frontiers in Ecology and the Environment 7:142-149.

Mascaro, J. and S.A. Schnitzer. 2007. Rhamnus cathartica L. (common buckthorn) as an ecosystem dominant in southern Wisconsin forests. Northeastern Naturalist 14:387-402.

Moody, M.E. and R.N. Mack. 1988. Controlling the spread of plant invasions: The importance of nascent foci. Journal of Applied Ecology 25:1009-1021.

Morghan, K.J.R. and T.R. Seastedt. 1999. Effects of soil nitrogen reduction on nonnative plants in restored grasslands. Restoration Ecology 7:51-55.

Packard, S. and C.F. Mutel. 1997. The Tallgrass Restoration Handbook. Washington, D.C.: Island Press.

Perry, L., D. Blumenthal, T. Monaco, M. Paschke and E. Redente. 2010. Immobilizing nitrogen to control plant invasion. Oecologia 163:13-24.

R Development Core Team. 2011. R: A language and environment for statistical computing. R Foundation for Statistical Computing, Vienna, Austria. www.R-project.org.

Rejmánek, M. 2000. Invasive plants: Approaches and predictions. Austral Ecology 25:497-506.

Rejmánek, M. and D.M. Richardson. 1996. What attributes make some plant species more invasive? Ecology 77:1655-1661.

Rhine, E.D., R.L. Mulvaney, E.J. Pratt and G.K. Sims. 1998. Improving the Berthelot reaction for determining ammonium in soil extracts and water. Soil Science Society of America Journal 62:473-480.

Robertson, G.P., P. Sollins, B.G. Ellis and K. Lajtha. 1999. Exchangeable ions, $\mathrm{pH}$, and cation exchange capacity. Pages 106-114 in G.P. Robertson, D.C. Coleman, C.S. Bledsoe, and P. Sollins (eds), Standard Soil Methods for Long-Term Ecological Research. Oxford University Press.

Runkle, J.R., A. DiSalvo, Y. GrahamGibson and M. Dorning. 2005. Vegetation release eight years after removal of Lonicera maackii in West-Central Ohio. The Ohio Journal of Science 107:125-129.

Silander, J.A. and D.M. Klepeis. 1999. The invasion ecology of Japanese barberry (Berberis thunbergii) in the New England landscape. Biological Invasions 1:189-201.

Simoni, J., B. Van Thiel and L. Wolthusen. 2012. Buckthorn Report. The Aldo Leopold Foundation. www .aldoleopold.org/images/enewsletter/ BuckthornReport2012.pdf.

Sollins, P., C. Glassman, E.A. Paul, C. Swanston, K. Lajtha, J.W. Heil and E.T. Elliott. 1999. Soil carbon and nitrogen pools and fractions. Pages 89-105 in G.P. Robertson, D.C. Coleman, C.S. Bledsoe, and P. Sollins (eds), Standard Soil Methods for LongTerm Ecological Research. New York: Oxford University Press.

Stevenson, F.J. and M.A. Cole. 1986. Cycles of Soil: Carbon, Nitrogen, Phosphorus, Sulfur, Micronutrients. New York: Wiley.

US Department of Agriculture [USDA]. 2012. Natural Resources Conservation
Service Web Soil Survey. websoil survey.nrcs.usda.gov/app/HomePage .htm.

Wedin, D. and D. Tilman. 1990. Species effects on nitrogen cycling: A test with perennial grasses. Oecologia 84:433-441.

Woods, K.D. 1993. Effects of invasion by Lonicera tatarica $\mathrm{L}$. on herbs and tree seedlings in four New England forests. American Midland Naturalist 130:62-74.

Zink, T.A. and M.F. Allen. 1998. The effects of organic amendments on the restoration of a disturbed coastal sage scrub habitat. Restoration Ecology 6:52-58.

Zuur, A.F., E.N. Ieno, N.J. Walker, A.A. Saveliev and G.M. Smith. 2009. Mixed Effects Models and Extensions in Ecology with R. New York: Springer Science and Business Media.

Basil V. Iannone III (corresponding author), Department of Biological Sciences, University of Illinois at Chicago, Chicago, IL 60607, bianno2@uic.edu.

Lauren G. Umek, Plant Biology and Conservation, Northwestern University, Evanston, IL, 60208; and Department of Plant Science, Chicago Botanic Garden, Glencoe, IL 60022.

Liam Heneghan, Department of Environmental Science and Studies, DePaul University, Chicago, IL 60614.

David H. Wise, Department of Biological Sciences, University of Illinois at Chicago, Chicago, IL 60607; and Associate Director, Institute for Environmental Science and Policy, University of Illinois at Chicago, Chicago, IL 60612. 